This item was submitted to Loughborough's Research Repository by the author.

Items in Figshare are protected by copyright, with all rights reserved, unless otherwise indicated.

\title{
The relationship between resource acquisition methods and firm performance in Chinese new ventures: the intermediate effect of learning capability
}

\section{PLEASE CITE THE PUBLISHED VERSION}

https://doi.org/10.1111/jsbm.12039

\section{PUBLISHER}

John Wiley \& Sons (@ International Council for Small Business)

VERSION

AM (Accepted Manuscript)

\section{PUBLISHER STATEMENT}

This work is made available according to the conditions of the Creative Commons Attribution-NonCommercialNoDerivatives 4.0 International (CC BY-NC-ND 4.0) licence. Full details of this licence are available at: https://creativecommons.org/licenses/by-nc-nd/4.0/

\section{LICENCE}

CC BY-NC-ND 4.0

\section{REPOSITORY RECORD}

Cai, Li, Mathew Hughes, and Miaomiao Yin. 2019. "The Relationship Between Resource Acquisition Methods and Firm Performance in Chinese New Ventures: The Intermediate Effect of Learning Capability”. figshare. https://hdl.handle.net/2134/26351. 


\title{
The Relationship between Resource Acquisition Methods and Firm Performance in Chinese New Ventures: The Intermediate Effect of Learning Capability
}

\begin{abstract}
Despite the omnipresent popularity of the resource-based view of the firm, our understanding of how firms convert resource acquisition into performance returns remains something of a black box. We seek to unpack this problem in this study. Building on the resource-based view and combining insights from organizational learning theory, this paper develops a theoretical model consisting of seven hypotheses in which resource purchase, resource attraction, and resource internal development are positively related to new venture performance and in which learning capability mediates these relationships. We also posit that resource acquisition methods augment the learning capability of the firm en route to securing superior new venture performance. We test these hypotheses using survey data from new ventures in China. The results indicate that all three methods of resource acquisition have positive effects on new venture performance; that resource attraction and internal development have positive effects on learning capability in new ventures; and that learning capability mediates the relationship between these two resource acquisition practices and new venture performance. We put forward implications for theory and practice to close the work.
\end{abstract}

Keywords: Resource acquisition; resource internal development; new ventures; learning capability; China. 


\section{Introduction}

Resource acquisition is gaining prominence as an important topic in the entrepreneurship literature. The process of acquiring resources such as financial, physical, human, and intangible resources from others is commonly acknowledged to be a vital entrepreneurial task during new venture creation (Shane 2003; Zhang, Soh, and Wong 2010). Obtaining adequate resources not only enables a new venture to pursue its identified opportunities, but also facilitates its ability to survive, grow, and generate profits in the face of competition (Shane 2003).

Competition is normally harder on a new venture because of its inherent resource constraints (Hughes, Ireland, and Morgan 2007; Stinchcombe 1965). The resource based view (RBV) has been considered as a guiding theoretical framework to help scholars to better understand how entrepreneurs running new ventures might strategically overcome this constraint (Alvarez and Busenitz 2001). The RBV is typically used to explain how firms might access and leverage unique resource stocks to outperform industry rivals (Barney 1991). However, this line of argument implies a path dependency in the relationship between the possession of resources and firm performance, which clouds the difficulties new ventures face in acquiring resources and converting these resources into performance rewards. For this reason, the process of resource management in a new venture remains a black box (Sirmon, Hitt, and Ireland 2007).

While resource acquisition might have an important effect on the performance of new ventures by closing resource gaps, what remains a mystery is what conditions might then influence the conversion of resources into any such performance returns. Previous studies in 
this area are mainly limited to new ventures acquiring resources in Western or developed markets with relatively stable institutional environments. But much less is known about how resource acquisition converts into performance in transitional economy countries such as China, which is moving from a centrally-planned economy to a market economy. After reform to the openness of China's economy, many new ventures emerged to drive contribution to China's economic growth. Recent theory developments in the area of capabilities and early firm survival and growth suggest that a learning capability will influence the path between resource acquisition and firm performance in new ventures. However, many new ventures in China tend to favor imitative learning from successful businesses which are aged and experienced, in part because of Confucian lore (Hitt, Ahlstrom, Dacin, Levitas, and Svobodina 2004). We contest though that new ventures will be better able to benefit from resource acquisition activities when investments are made into the firm's learning capability. As a pathway to this, we also propose that resource acquisition activities themselves provide a platform to stimulate such a learning capability.

Our reasoning is based on recent theory developments that have questioned the constraints placed on a firm by its newness (Autio, Sapienza, and Almeida 2000; Sapienza, Autio, George, and Zahra 2006). Historically, new ventures were deemed to exhibit weak resource stocks that crippled their capacity to compete against incumbent firms, the net effect being poor performance (e.g., Henderson 1999; Stinchcombe 1965). However, this assumption has been challenged on at least two grounds. First, a firm's liabilities evolve as the firm ages and as its managers generate experience and paradigms on how the firm should compete in its chosen markets (Henderson 1999). Such experience may cause core rigidities 
to emerge-rigidities that undermine any relationship between resource ownership and performance (Leonard-Barton 1992). Consequently, some form of a learning capability is needed to renew the relationship between resources and performance (Eisenhardt and Martin 2000). Second, and more specific to new ventures, new and young venture firms lack historical knowledge, experience, routines, and paradigms to constrain the boundaries of its resource search and acquisition efforts (Audretsch and Lehmann 2006; Sapienza et al. 2006). Equally, the new venture is not constrained by expectations of how it is meant to compete in a market place. The net effect is that new capabilities emerge as it purchases resources from the market, attracts resources from stakeholders, and develops new ones internally. This process may give new ventures learning advantages that increase the probability of growth and superior firm performance (Autio et al. 2000; Sapienza et al. 2006).

An organizational learning capability captures the extent to which a firm implements appropriate management practices, structures, and procedures that enables the exchange and integration of knowledge from experience into a body of collective knowledge that shapes organizational know-how on resource use and organizational behavior to take place, helping it in turn to better manage competition (Audretsch and Lehmann 2006; Goh 1998; Jerez-Gómez, Céspedes-Lorente, and Valle-Cabrera 2005; Leonard-Barton 1992). We propose that organizational learning capability reshapes the relationship between resource acquisition and new venture performance by dynamically changing the integration and recombination of resources into new value creating strategies for the firm (Eisenhardt and Martin 2000), enabling the new venture to better adapt to its environment (Sapienza et al. 2006). 
By exploring and testing this causal logic, we offer two important and interesting contributions to the body of knowledge on resource acquirement and new venture performance in China. First, we examine how three different resource acquisition methods (buying from markets, attraction from partners, and internal development) affect organizational learning capability and new venture performance, thereby unpacking the black box between resource acquisition and firm performance in new ventures. And second, we test the mediating effect of learning capability on the relationship between resource acquisition and new venture performance, thereby offering empirical evidence of the 'learning advantages of newness' thesis as put forward by Autio et al. (2000) and Sapienza et al. (2006).

We begin by introducing the concepts of resource acquisition methods, learning capability, and new venture performance. Then we develop our theoretical framework and put forward seven hypotheses concerning the relationships among resource acquisition, learning capability, and new venture performance. Thereafter we report our methodology to examine and test these hypotheses using data from a sample of new ventures in China. The paper concludes with a discussion of the implications of our findings for theory and research on resource acquisition, learning capability, and new venture performance, as well as implications for managers.

\section{Concepts and theory background}

Resource Acquisition. Regardless of how we might frame the mechanisms associated with liabilities of newness, it is apparent that new ventures lack resources and proven competencies. In turn, acquiring resources (such as finding investors, land, materials, technology, equipment, facilities, employees, associates, and customers) is a principal 
challenge for the entrepreneurs behind new venture firms. Pfeffer and Salancik's (1978) resource dependency theory posits two steps in the resource acquisition process for firms. The first step is to determine the type of resources required and the sources of them; while the second step is searching for the means of access to such resources. Through analyzing resource requirements and considering what existing resources are available, new ventures can decide which resources they need to acquire from the environment and the method of acquisition most pertinent to the firm. In this sense, resource acquisition is defined as the process by which new ventures acquire resources from the internal and external environment.

Previous research indicates that new ventures use their stock of resources to acquire additional resources in a variety of ways. New ventures can purchase other resources with their financial resources, they can attract resources through their intangible ones, and they can develop or accumulate resources internally (Brush, Greene, Hart, and Haller 2001). For example, Sirmon and Hitt (2003) suggest that entrepreneurial firms can acquire resources from external factor markets or they can develop new resources internally by combining and configuring existing resources in novel ways. Bowman and Collier (2006) posit a third route to resource acquisition through alliances and network relationships. The literature on strategic networks suggests that a new venture can draw on relationships to gain access to a pool of resources that would otherwise be difficult to get hold of (Hughes et al. 2007). Strategic networks can also offer rapid access to scarce resources in a way that is superior to either market exchange or internal development (Gulati, Nohria, and Zaheer 2000). To this end, entrepreneurs can use external relationships to attract resources and change the constraints affecting the firm (Pfeffer and Salancik 1978). Consolidating this literature, we put forward three primary resource acquisition methods that new ventures can deploy: (1) purchase, (2) 
attraction, and (3) internal development.

Resource purchase is the process through which new ventures buy target resources from the external factor market with their initial financial resources (Barney 1986). Purchase is a direct and one-time approach to obtaining a necessary resource for the new venture, such as buying patents, licensing or sourcing technology resources, buying or renting land or equipments to acquire physical resources, recruiting employees to enrich human resources, and buying materials for production. Ownership of the target resources enables the new venture to fully control the application, use, and deployment of those resources going forward. This is particularly important when a resource is core to the firm's market initiatives. Whether to buy resources or not depends on the availability of the resource in the marketplace, its cost, and how critical its acquisition is to get the firm to market quickly. The greater the firm's urgency to get to market with a competitive and viable offering, the more likely the new venture will purchase the resource in question because the cost of the resource is then fully justified. If developing the resource (for example service technology) diverts key human and business resources from more important tasks (such as managing customers), the new venture is again more likely to make a purchase decision than adopt any other form of resource acquisition (Brush et al. 2001). Purchased and wholly-owned resources offer managers more control over the value created by their use, albeit with an adjustment made for their cost (Sirmon et al. 2007).

Resource attraction occurs when new ventures acquire target resources from outside the firm indirectly through non-financial means. Attraction includes acquiring resources (such as know-how, financial resources, skilled employees, or product-services) by informal 
cooperation (social network) or formal alliance (governed by a contract, for example). But any such method can only acquire the right to use those resources and does not offer any ownership unless they are co-developed in some way. Thus, while resource attraction carries lower financial cost typically, the investment of time into the relationship (for example to build the requisite social capital) and the need to reciprocate with one's own resources can create additional costs (Hughes et al. 2007). The new venture’s lack of legitimacy, reputation, and track record can create a sense of risk on the part of potential resource providers though (Brush et al. 2001). Entrepreneurs must therefore build trust by demonstrating merit, fidelity, worthiness, and reliability in their relationships with external partners. This can be achieved by deploying business plans, experienced staff, and burgeoning reputation to create a professional image that will encourage potential resource providers to commit resources to the new venture (Brush et al. 2001). In this way, the new venture builds social relationships that will enable it to access other forms of external resources at a reduced cost (Nahapiet and Ghoshal 1998). The greater the new venture firm's efforts towards resource attraction, the stronger its social capital becomes to attract yet further and more exclusive resources in time.

Internal resource development processes as an aspect of resource acquisition develops the firm's resource stock in a way that offers exclusive advantages to the firm. By expanding on the unique combinations and configurations of resources to be deployed by the firm (Bowman and Collier 2006; Sirmon et al. 2007), managers can develop the heterogeneous, rare, and difficult-to-imitable resource bundles and capabilities that will differentiate the firm’s performance from its competitors (Barney, 1991). Internal resource development is often necessary because strategic factor markets are unlikely to provide a new venture with 
all the resources it needs (Sirmon et al. 2007). The internal development of resources can occur in several ways. The firm can build or make its own equipment by refining or reapplying technology; it can deploy $\mathrm{R} \& \mathrm{D}$ to develop need technologies and patents; it can train and allocate experienced staff to work on new innovations; or it can accumulate resources and capital inside the firm over time. Such a process of resource and competence exploration and exploitation can lead new ventures to develop superior resources bundles that carry fewer rigidity risks in the long term (Atuahene-Gima 2005).

Learning Capability. As market competition becomes increasingly more intense, new ventures need organizational learning to develop and maintain better competitive positions. Organizational learning has therefore become a necessary instrument for firms to secure competitive advantage and improve performance (Senge 1990; Garvin 2000). In this sense, the urgency to develop an organizational learning capability-which enables a firm to implement appropriate management practices, structures, and procedures that facilitate and encourage learning (Leonard-Barton 1992; Goh 1998)—has become an important priority for entrepreneurs and managers.

Increased $R \& D$ activities in a firm help to develop a learning capability to identify, assimilate, and make use of external knowledge, but the effectiveness of such a capability is also contingent on its past experience and past accumulated knowledge (Cohen and Levinthal 1990) and on the processes in the firm to transform knowledge into meaningful outcomes of relevance to the firm (Hsu and Fang 2009). Learning capability is one kind of capability which can help firms carry out management practice, build new businesses and innovations, and establish new routines to facilitate and encourage greater knowledge exploration and 
exploitation in the firm (Akgun, Keskin, Byrne, and Aren, 2007).

A skills-based view of learning capability however does not fully capture the complexity or richness of the concept. Organizational learning is "the product of individual and group learning applied to the accomplishment of the organization's vision and performance goals and that certain management practices and internal conditions can either help or hinder this process” (Goh and Richards 1997, p.577). Thus, a firm’s learning capability is made up of internal firm conditions and management practices that lead to learning. Five key conditions have received support in the literature: clarity of purpose and mission, leadership commitment and empowerment, experimentation and rewards, transfer of knowledge, teamwork, and group problem solving (Goh and Richards 1997; Hult and Ferrell 1997; Jerez-Gómez et al. 2005). These conditions, and the capability they underpin, enable a firm to 'learn' through the effective creation, acquisition, processing, transference, and integration of knowledge (Jerez-Gómez et al. 2005). In summary, we define an organizational learning capability as the extent to which a firm implements appropriate management practices, structures, and procedures that enable the exchange and integration of knowledge from experience into a body of collective knowledge that shapes organizational know-how on resource use and organizational activities to manage competition (Leonard-Barton 1992; Goh 1998; Jerez-Gómez et al. 2005). Such a capability optimizes organizational structures that make organizational learning processes fluid and efficient to develop new products/services that then enhance firm performance (Costa and Queiroz 2002).

New Venture Performance. Business performance not only reflects organizational effectiveness (Venkatraman and Ramanujam 1986) but also the results of a firm’s operations. 
Superior performance in new ventures is typically associated with successful business development, which in turn generates robust returns on investment and growth in sales, volume, profit, market share, and employment (Jennings and Beaver 1997; Lumpkin and Dess 2001; Venkatraman and Ramanujam 1986). Murphy, Trailer and Hill (1996) reviewed the empirical entrepreneurship literature from 1987 to 1993 and found that a majority of performance measures were related to efficiency, growth, profit, size, liquidity, success/failure, market share and leverage; although growth and profit were the most commonly considered dimensions. Performance is therefore multidimensional, and so it is advantageous to integrate different dimensions of performance when studying new ventures. We define new venture performance as being made up of both financial performance and growth performance.

\section{Research Model and Hypotheses}

According to the resource-based view (RBV), new venture performance is directly related to resource acquisition because the availability of resource is a significant factor in understanding firm performance (Barney and Arikan 2001). To achieve a comparative and process view of resource acquisition (Bowman and Collier 2006), we posit that different resource acquisition methods a firm might pursue (resource purchase, resource attraction, and resource internal development) might generate varying performance outcomes based on the extent to which a resource is new, is wholly owned by the firm, or is a product of a set of relationships the firm holds with partners. No matter what method is used to acquire resources, a cost is involved either in terms of direct funding or in terms of effort. Acquiring technologies, patents, materials, equipments, capital, and employees constitute the main 
content of cost structure for Chinese new ventures. Thus, by 'resources' we refer to these resources in particular.

New ventures can acquire resources through internal and external means. Organization learning in the process of carrying out business activities relies on information or knowledge from internal and external organizations being brought into the firm. As the firm learns from its resource acquisition activities, the firm receives opportunities to adjust its aims, strategies, and behaviors to improve the balance of the relationship between the firm's inputs and outputs within its environment (Argyris and Schon 1978; Shrivastava 1983).

According to organizational learning theory, new ventures need to acquire, distribute, and absorb information and knowledge to improve new venture performance (Gilbert, McDougall, and Audretsch 2008). But the extent to which this happens depends on the learning capability of the firm, and the extent to which it has the right structures and processes in place to convert information and knowledge into learning of meaning to the firm. The process of resource acquisition creates unique learning opportunities for Chinese new ventures to acquire information and knowledge from external resource providers and through internal resource development processes (Uhlenbruck, Meyer, and Hitt 2003). Because resources are not easy to obtain, new ventures have to expend significant effort in acquiring or developing resources. Undertaking such activities requires the firm to engage in search, development, problem-solving, and negotiation actions that shape opportunities to learn. For example, new ventures need to learn how to bargain with suppliers in factor markets; learn how to communicate with partners in order to negotiate and attract resource for gratis or for better terms; and learn how to develop difficult to imitate resources themselves. These 
idiosyncratic learning encounters create impetus, motivation, and drive for firms to change their structures and processes to shape a learning capability that enables them to take increasingly better advantage of these learning opportunities (Dibella, Edwin, and Gould 1996). A strong learning capability in turn should help to convert resources into better performance because the learning that takes place as part of the resource acquisition and resource integration process shapes unique insight into their usefulness and value to the firm. To summarize, we expect resource acquisition to positively and directly affect new venture performance, but we also expect learning capability to play a medial role between resource acquisition and performance. Figure One summarizes the relationships expected among resource acquisition, learning capability, and new venture performance.

----------Insert Figure One here

The Relationship between Resource Acquisition and New Venture Performance. From a RBV perspective, the challenge for a new venture is to identify, acquire or develop strategic resources that are rare, immobile, imperfectly imitable, and non-substitutable because such resources can deliver competitive advantage (Barney 1986), when deployed in an appropriate manner (Sirmon et al. 2007). But firms also need to purchase such resources below their 'true' future value to accrue meaningful return from them. Therefore, if new ventures need to buy resources from factor markets, it is necessary for the firm to be able to identify those undervalued resources. Resources are undervalued in factor markets when their true future value can only be appreciated if they are acquired by firms who have reasonable intellectual capital to understand how they might be helpful to value creation. Such events are possible during the transitional time in China because strategic factor markets have incomplete 
information on new resources or old resources that will be used in new ways (that is, such new combinations and uses are unknown to the market because of the dynamic rate of change taking place). In turn, these markets cannot accurately price these resources. Owing to this uncertainty, there are opportunities for new ventures to purchase resources below their true market value (Denrell 2003) such that resource purchasing can positively affect new ventures’ financial performance.

Purchasing resources from sources outside the firm can also help a firm to avoid a path dependence trap. For example, purchasing resources that are new to the firm can prevent the firm from locking into a particular product, service, technology, resource, or competence path, or on depending upon existing products, services, technologies, resources or competencies, either, because new resources from outside the firm can be used to change the firm's strategic direction significantly, or enable it to respond to uncertain environmental conditions more readily as they emerge (Mathews 2003). The availability of resources has been reported to positively affect firm growth (Castrogiovanni 1991; Covin and Slevin 1991; Vesper 1980), because resources are the basic materials from which the firm can develop its market activities and manage competition. The strategic options available to a firm are therefore broader if its resources are acquired from various sources (Romanelli 1987). By having access to resources, a new venture's ability to learn, to innovate and to operate is enhanced, and so growth performance would also be expected to improve. Thus:

Hypothesis 1a: Resource purchase has a positive effect on new venture performance.

It is commonly appreciated that new ventures suffer from liabilities of newness such that their initial resource endowments are incomplete and inadequate to achieve the task of 
venture growth. A particular form of this liability is a lack of financial resources in China, and it is therefore not possible for a new venture to simply 'purchase' all the resources they need. As a result of this dilemma, new ventures often make use of social networks, signaling their quality where possible (for example, through a polished business plan, or through prestigious location and facilities that signal their serious intent), or effective storytelling in ways to create an image of success that will help them to attract resources (Brush et al. 2001). When new ventures seek to attract resources from their co-partners efficiently and quickly, and expand this resource base rapidly, they develop opportunities to grow quickly. Building social capital between the firm and its potential resource partners provides an appropriate way for new ventures to overcome resource barriers in the short term, and enhance their business performance in doing so (Hughes et al. 2007; Premaratne 2001). Therefore, resource attraction can positively affect the performance of new ventures.

Based on social network theory, an entrepreneur's direct or indirect connections to potential resource providers are very important at the early stage of firm growth (Hall and Hofer 1993; Hite and Hesterly 2001; Pirolo and Presutti 2010; Steier and Greenwood 2000). It is perhaps unsurprising therefore that scholars have observed how firms that lack sufficient resources to fuel firm development frequently use social networks to attract complementary resources from relevant actors (Johnson and Sohi 2003). When new ventures cannot purchase resources simply from factor markets (Chi 1994), a network is helpful for firms to access needed resources (Das and Teng 2000). Within a network new ventures can share valuable resources (Eisenhardt and Schoonhoven 1996; Molina-Morales and Martínez-Fernández 2010), and pursue currently unobtainable market opportunities, therefore offering novel 
opportunities to enhance firm performance in unusual ways.

New ventures can also attract resources through signaling their quality. A track record, top management team characteristics, certifications and endorsements, and affiliations with high-status third parties can reflect quality signaling on behalf of firms (Shane and Cable 2002). Given the liabilities of new ventures, if they develop an early reliable track record and good reputation, it becomes easier for them to attract resources from potential providers. Signaling quality is helpful to attract resources and enhance new ventures' performance because the transaction costs (of sorts) placed on the investment falls as the firm conveys its trustworthiness. For example, greater trustworthiness should result in a lower interest charge on financial capital attracted from resource partners because the perception of risk is reduced by the firm's signaling of its honorable intentions and its potential for growth-although this is not withstanding the need to portray accurately the potential of the firm, and not demonstrate unnecessary optimism that may not be a valid reflection of the firm's actual potential (Dushnitsky 2010). Effective storytelling can also reduce the uncertainty perceived by potential resource suppliers (Lounsbury and Glynn 2001; Pollock and Rindova 2003; Shane 2003; Stuart, Hoang, and Hybels 1999), and motivates and mobilizes them into committing resources to a new venture (Martens, Jennings, and Jennings 2007). But such efforts are worthwhile as attracting resources by developing valuable ties with important actors can enhance possibilities for wealth creation and better new venture performance as a result (Brush et al. 2001). Thus:

Hypothesis 1b: Resource attraction has a positive effect on new venture performance.

Key resources that are vital for shaping competitive advantage are generally rare, 
immobile, imperfectly imitable, and non-substitutable (Barney 1991). Resources are immobile when it is difficult to move or transfer resources from one firm to another, typically due to enormous cost. Resources are imperfectly imitable and non-substitutable when they are difficult to directly acquire from outside the firm. Resource internal development can play an important role in enhancing new venture performance because internally developed resources emerge from a complex bundling, reconfiguration, and recombination process that is dependent on tacit knowledge (Sirmon et al. 2007). Moreover, firms that develop resources internally build new routines over time that enable it to better explore new resource combinations while steadily improving upon its experience of existing resource bundles (Bowman and Collier 2006). Over time, a firm may develop valuable and rare resources through this process, and because path dependence in one firm is unique, it can develop resources in a unique manner that other firms cannot readily imitate, unless they have taken a near-identical path over time (an event that is highly unlikely due to the idiosyncratic nature of resource bundling, the unique context in which a new venture operates, the unique know-how and knowledge that fuels the process, and the unique aims of the firm in undertaking this task). For example, internal activities to innovate with resources in conjunction with improved training can assist the employees of Chinese firms to not only develop new resource combinations but also to develop their own knowledge and professional skills in unique ways. In turn, the firm can benefit in multiple ways from internal resource development activities as these activities encourage and help enable employees to create more value for the firm. Therefore, developing internal resources continuously can expand the efficiency of various resources and also raise the rent-creating potential of 
resources, providing a basis for improved new venture financial performance. Given the liabilities of newness in new ventures, and the particular circumstances that existed when the firm was established, the internal development process can result in the creation of unique resources that cannot be readily duplicated or acquired from external sources. Thus, resource internal development would be expected to offer a basis to enhance new ventures' financial performance. Thus:

Hypothesis 1c: Resource internal development has a positive effect on new venture performance.

The Relationship between Learning Capability and New Venture Performance. A long-held belief in the research base on organizational learning is that a learning capability can improve organizational performance (Fiol and Lyles 1985). Many firms recognize that in order to respond to rapidly changing environmental conditions, firms need constant adjustment and innovation. Adjustment and innovation are fueled by knowledge and so a firm's capability to learn becomes an increasingly important and necessary condition for business survival. Developing and enhancing a firm's learning capability so that an effective environment exists within the firm to devise solutions to emerging business problems and challenges should be beneficial to the firm's survival and success (Lynn and Akgun 2000). Scholars have also reported that learning capability can have a positive effect on performance through product innovation (Akgun et al. 2007).

Organizational learning refers to any change in the organization's operation that maintains or improves performance (Dibella et al. 1996; Fiol and Lyles, 1985). The organizational learning process consists of acquisition, dissemination, and use of knowledge, and is closely 
related to firms’ performance (Argote, McEvily, and Reagans 2003; Lemon and Sahota 2004). Learning capability through knowledge acquisition, dissemination, and sharing is an important intangible asset of an enterprise. It can change employees' cognition and behavior, which promotes faster firm growth. Therefore, only new ventures that develop and upgrade their learning capability so that communication and sharing of knowledge and information is efficient, timely, and effective can arguably realize truly superior performance (Sapienza et al. 2006).

The organizational learning process is not automatic and whether or not any degree of learning takes place or is meaningful to firm performance depends on the firm's actual capability to learn (Jerez-Gómez et al. 2005). A learning capability is multidimensional and flows from the structural capital of the firm (Hsu and Fang 2009). A firm that possesses a strong learning capability will need to have made investments into developing a clarity of purpose, vision, and mission; demonstrate leadership, commitment and empowerment towards learning behaviors; promote experimentation of new ideas and reward new ideas that result in valuable outcomes for the firm; and enable the transfer of knowledge through teamwork and group problem solving (Goh and Richards 1997; Hult and Ferrell 1997; Jerez-Gómez et al. 2005). These conditions capture the extent to which a firm implements appropriate management practices, structures, and procedures that enables the exchange and integration of knowledge to take place (Hsu and Fang 2009; Ulrich, Glinow, and Jick 1993). Without these organizational structures, systems and processes underpinning the environment of the firm being in place, a body of collective knowledge that shapes organizational know-how on resource use and organizational behavior will emerge only in an idiosyncratic 
or emergent sense, with few if any processes in place to generate common understanding and meaning of new knowledge or to disseminate and leverage it within the firm (Crossan, Lane, and White 1999). Without the capability to convert knowledge into value for the firm, the new venture will not be able to acquire the performance benefit of learning events (Leonard-Barton, 1992; Goh, 1998; Jerez-Gómez et al. 2005). Thus:

Hypothesis 2: Learning capability has a positive effect on new venture performance.

The Mediating Effect of Learning Capability between Resource Acquisition and New Venture Performance. The resources bought from factor markets alone are potentially insufficient to create rents for firms. According to extant research, resources should be transformed into capabilities that help firms to get more rents (Chandler and Hanks 1994; Brush et al. 2001). A capability represents an ability "to perform a coordinated set of tasks utilizing organizational resources” (Helfat and Peteraf 2003, p.999). Accordingly, resources bought in from outside the firm provide the basis for developing a learning capability that helps shape unique avenues of performance. Scholars have proposed that resources are bought to alter current capabilities or to create new ones in response to environmental changes (Eisenhardt and Martin 2000). Therefore, new ventures can buy resources from factor market and use them to shape a learning capability. In return a learning capability can aid in the conversion of resources into further new capabilities that then form and underpin competitive advantages (Eisenhardt and Martin 2000). Thus purchasing resources can enhance firms' learning capability directly and then help new ventures to shape greater rents.

From our definition of learning capability presented earlier, there are conditions (clarity of purpose and mission, leadership commitment and empowerment, experimentation and 
rewards, transfer of knowledge, teamwork, and group problem solving) that underpin a learning capability. The process of resource purchase strengthens these conditions to positively influence firms' outcomes. Firstly, before new ventures buy resources, entrepreneurs and employees should know the firm's strategic aims, vision, and mission. It is on this basis that entrepreneurs can decide what kind of resources they need and which resource suppliers can provide such resources. Understanding the firm's missions clearly will help employees improve search behaviors, which ignites organizational learning. The learning that takes place encourages a learning capability to form so that the firm can better take advantage of the learning it acquires during resource acquisition. This process should help new ventures make more rents in turn.

Secondly, resource purchase is helpful to build management commitment towards learning in new ventures. Entrepreneurs need to make decisions on what resources new ventures should buy, where they can get the target resources, and when they will buy the target resources. This process needs entrepreneurs to make more commitments towards understanding their new venture's resource requirements and how these map onto intended growth strategies. Doing so will also signal to and encourage employees to make contributions towards meeting resource requirements and growth aims. During this process, organizational learning capability will likely improve because an emphasis is being placed on learning about the business and mapping that knowledge to the business realities facing the firm. Thirdly, buying new resources from factor markets will lead new ventures to construct new resources bundles and produce new capabilities, which is helpful for a new venture to renew itself. Contacting with new supplies will lead new ventures to build new relationships, 
which induces new ventures to face up to new challenges (Lei, Slocum, and Pitts 1999). It is also helpful for new ventures to avoid path dependency since new resources can inject new blood into the enterprise. Therefore, buying resources from outside markets positively influence new ventures to develop a culture that is learning oriented. Buying resources from outside markets can also diversify the resources owned by a new venture, allowing its knowledge base to be widened, and improved (Senge 1990; Leonard-Barton 1992; Sinkula 1994). Fourthly, resource purchase also promotes knowledge transfer and integration in new ventures. During the process of buying resources, new ventures need to communicate, bargain, debate, and negotiate with resource suppliers. These activities promote information and knowledge transfer among these actors. In total, we expect that buying resources from outside the firm can promote a learning capability to develop to then strengthen firm performance. Thus:

Hypothesis 3a: Learning capability mediates the relationship between resource purchase and new venture performance.

A resource attraction process can promote learning capability indirectly through the learning experiences that are encountered during the process of building valuable relationships with potential resource providers. Building relationships with other firms in time should make it easier for firms to attract additional resources for several reasons. Firstly, relationships are a good means to transfer knowledge among network actors (Lane and Lubatkin 1998). New knowledge resources attracted from outside the firm can stimulate change and improvement in the practices of the business (Hughes et al. 2007). We posit that part of this improvement relates directly to upgrading of the firm's learning capability. In 
support of this view, resource attraction has been associated with greater knowledge transfer and integration, which then offer opportunities to improve firm performance (Makino and Delios 1996; Tsai 2001). Secondly, making relationships with other firms may help new ventures develop a learning-oriented business culture. As new ventures communicate and contact with network actors to attract resources, these new ventures gain new information and knowledge that promote new venture to develop a learning capability (Goh and Richards 1997; Jerez-Gómez et al. 2005). The learning capability helps convert and integrate knowledge from these learning encounters to further strengthen the relationship between attracted resources and firm performance. This is likely because the firm will learn experiences in making use of resources from others (Argote and Ingram 2000), which is helpful to improve learning capability. Employees’ personal relationships are helpful for them to get involved in management in new ventures. For example, this activity promotes teamwork and solving problems in group, which is one condition to develop learning capability (Jerez-Gómez et al. 2005). In summary, attracting resources from other companies through relationships promotes the storage and application of knowledge. Knowledge transfer will improve learning capability through improvements in knowledge or behavior of the recipient firm, thereby helping an organization to strengthen their performance. Thus:

Hypothesis 3b: Learning capability mediates the relationship between resource attraction and new venture performance.

Resource internal development can accumulate skillful experiences and important information and knowledge about the firm's base of resources, fuelling the development of new resources and new combinations, but also fuelling a dynamic learning environment as 
employees learn new uses for firm resources (Sirmon et al. 2007). Resource internal development more than any other form of resource acquisition is likely to lead to organizational learning that stimulates improvement in the firms' learning capability. And that capability in turn reciprocally improves the use and development of internal resources (Sirmon et al. 2007). For example, resource internal development includes the training of multi-functional employees (Gerwin and Kolodny 1992) and incorporating employee suggestions (Hall 1987) into process and product development, which reflects an organizational learning process. New ventures could enhance their internal resource contribution rate and improve their organizational knowledge through resource internal development. Greater numbers of exploration activities to develop and accumulate superior internal resources facilitates organizational learning. The structures needed to facilitate explorative activities are typically associated with loosely-coupled systems and procedures that encourage employees to look at new ways of doing things (He and Wong 2004). This loose-coupling encourages information sharing so that employees play to discover new resource combinations that are not locked into the past ways of the business (March 1991). It would be expected then that these activities shape a learning capability and they mirror the positive environment that conditions learning capability in firms (Goh and Richards 1997; Hsu and Fang 2009; Hult and Ferrell 1997; Jerez-Gómez et al. 2005). During this cumulating process, new ventures can form path dependence, which is difficult for competitors to imitate. The process will strengthen organizational learning, which in turn leads to superior performance (Schroeder, Bates, and Junttila 2002).

Knowledge transfer and integration is promoted by resource internal development. 
During the process of resource internal development, firms will need to reduce internal barriers that impede the transfer of best practices within the firm (Szulanski 1996), which makes knowledge transfer more straightforward. Thus, resource internal development is helpful for knowledge to be generated and applied, which increase the rate of firm learning to a near-constant rate as barriers to learning break down (and so the conditions for an effective learning capability emerge) (Jerez-Gómez et al. 2005). It also includes looking for innovative solutions to problems, distinct methods and procedures to use (Chiva, Alegre, and Lapiedra 2007). Resource internal development needs communication and cooperation among employees. This process is then helpful for new ventures to establish teamwork. Therefore, resource internal development positively influences the conditions that underpin learning capability. In summary, we propose that learning capability has an intermediating effect between internal resource development and performance. Thus:

Hypothesis 3c: Learning capability mediates the relationship between resource internal development and new venture performance.

\section{Methodology}

Sample. In order to test the relationships put forward in this paper, we collected data from new ventures in China with a questionnaire survey approach. Following the 2006 Global Entrepreneurship Monitor China Report, we can classify Chinese provinces or districts as four kinds of areas based on their index of entrepreneurship activity, namely high active area, general active area, non-active area, and quiet area. In order to make the sample representative, we chose Jilin province from the non-active area, Fujian Province from the general active area, and Guangdong province from the high active area. Based on the 
National Bureau of Statistics of China, the number of employees for small firms should not be higher than 300 in manufacturing industry; 600 in environment protection; 100 in automobile; 500 in modern agriculture; 100 in tenancy and business service; 600 in construction; 100 in real estate; 500 in traffic and post; 100 in storage; 100 in retailing; 100 in communication, computer service and software; and 100 in other industries.

Our primary sampling frame was 1000 firms. The following criteria were used for choosing the sample: (1) the firms must be started by entrepreneurs and are not controlled by other firms; (2) the firms must be less than 8 years old to show they are new ventures (Biggadike 1979; McDougall and Robinson 1990; Miller and Camp 1985; Wong et al. 1993; Zahra 1993); (3) the number of employees must accord with the criterion of small firms set out by the National Bureau of Statistics of China.

The questionnaire was developed using items and concepts drawn from previous studies. We consulted extensively with managers of various firms to ensure translation accuracy, to examine the appropriateness of items, and to ensure that the survey corresponded to actual business conditions in China. To the end, a pilot study was conducted with 10 firms (excluded from the final survey sample). We then revised the initial questionnaire based on the feedback we received.

Data collection was performed in two steps. First, we arranged appointments with the firms by telephone. Second, we surveyed the founders and requested them to finish the questionnaire completely. The principal founder of each firm was interviewed for this research. Such key informants have proven to be accurate sources of data (Brush and Vanderwerf 1992). Such a single respondent is particularly appropriate in China due to the 
hierarchical nature of the decision-making process in a Chinese firm (that is, the vast if not total control of the entrepreneurial firm rests with the entrepreneur founder as the single key decision-maker).

A total of 1000 enterprises were approached. A total of 343 eligible firms provided all the necessary data, providing a response rate of 34.3 percent. We excluded those questionnaires that were inadequately completed. Table One summarizes the characteristics of the sample firms.

----------Insert Table One here

Variables and Measures. Seven-point Likert scales are used to measure all the items. These measures are mostly from previous studies and we made some modification during the translation process. We translated the measures into Chinese and then proceeded to a back-translation process in order to check for accuracy. The three methods of resource acquisition and learning capability were measured using statements anchored "Strongly disagree” (1) to "Strongly agree” (7), while performance was measured using statements anchored “very low” (1) to "very high” (7).

Based on the research of Brush et al. (2001) and Sirmon et al. (2007), we use four items to measure resource purchase, twelve items to measure resource attraction, and four items to measure resource internal development. We sourced the eighteen items measuring learning capability from Goh and Richards (1997) and Jerez-Gómez et al. (2005). Finally, we use nine items to measure new venture performance sourced from Lumpkin and Dess (2001). The performance data was self-reported by the entrepreneur managers. We also recorded firm area (location), firm age and firm size as control variables since these conditions can be 
illustrative of greater resource stocks within firms.

We made pre-test with scholars, entrepreneurs, and experts in order to check the face validity and content validity of the questionnaire items. Following their suggestions, we modified some aspects of sentence tone, word order, and order of items within the questionnaire. The items used can be found in Table Two.

-----------Insert Table Two here

As reported in Table Two, except for the loadings of RA1, RA8, and RA12, which are below 0.5, all other factor loadings are acceptable at above 0.5. We subsequently deleted these three items from the reminder of the data analysis. The $t$-values of all items are significant $\left({ }^{* *} \mathrm{p}<0.01\right)$. Model fit is also strong with the CFI and IFI no less than 0.9 , while GFI and TLI are nearly 0.9. The RMSEA of 0.048 further indicates the acceptability of the model. The Chi-Square/d.f. is equal to 1.78, which exceeds accepted levels (Bollen 1989). We also examined the reliability of each construct in terms of Cronbach alpha coefficients. These results can be seen in Table Two. All Cronbach alpha coefficients except resource internal development are equal or greater to 0.7 , suggesting satisfactory reliability (Nunnally 1978). The Cronbach alpha of resource internal development is over 0.60 , which is considered acceptable due to the new setting of the research compared to past studies (Nunnally 1978).

Common Method Bias. We use Harman's one-factor test to examine whether common method bias affects the data (Podsakoff and Organ 1986). If a single factor is extracted to explain a majority of the variance of the data, then common method variance exists. Using exploratory factor analysis to examine all the variables simultaneously, the un-rotated factor 
structure does not indicate a single-factor structure. Specifically, the independent variables and the dependent variable do not load onto the same factor. In addition the first factor only explains 25.89 percent of variance in the data. Therefore, common method bias does not appear to be a present in the data.

\section{Results and Analysis}

Table Three presents the descriptive statistics and correlation matrix of the study constructs. The correlation matrix indicates that bivariate associations exist among the constructs of interest in this study and so provide an initial platform to interpret our predicted relationships. To examine direction, we employ regression analysis.

----------Insert Table Three here

To examine the hypotheses we use SPSS 16.0 software and adopt regression analysis. This method allows us to test the direct and mediated relationships put forward in our conceptual framework (Baron and Kenny 1986). Firstly, we select area, firm age and firm size as variables to be controlled for. Table Four shows that model I is the basic model and in model II we add the explaining variables to explore the relationships between resource acquisition methods and new venture performance. $R^{2}$ increases to 0.219 from 0.02 , increasing by 0.199 , which indicates that the independent variables (resource acquisition methods) explain considerably more variance in the dependent variable (new venture performance) than do the control variables. The $F$-value is also significant in model II. In model II we can see that the standardized regression coefficient $(\beta)$ of resource purchase is 0.173 and is significant $(p=0.008)$. The standardized regression coefficient $(\beta)$ of resource attraction is 0.190 , and also significant $(p=0.002)$. The standardized regression coefficient $(\beta)$ of resource internal development is 0.245 and is significant $(p=0.000)$ as well. As such, 
hypotheses 1a, 1b, and 1c are fully supported.

-----------Insert Table Four here

Following Baron and Kenny (1986) we adopt the following three steps to examine the mediation effects of learning capability between three methods of resource acquisition and new venture performance. Table Five shows the results of the mediation tests. In each step the regression model possesses statistically significant $F$-test values and so the models possess good explanatory power.

-----------Insert Table Five here

From Table Five we obtain evidence that hypothesis H1a $(\beta=0.16, p=0.008)$, hypothesis H1b $(\beta=0.211, p=0.001)$, and hypothesis H1c $(\beta=0.229, p=0.000)$ are supported through this examination, denoting that resource purchase, resource attraction, and resource internal development have direct positive effects on new venture performance. Table Five shows that hypothesis $\mathrm{H} 2$ is supported $(\beta=0.416, p=0.000)$, which indicates that learning capability has a positive effect on new venture performance.

Further following Baron and Kenny (1986), we examine the intermediate effect of learning capability between resource acquisition and new venture performance. There are three steps in the process of examining for a mediating effect. In the first step we examine the relationship between dependent variables and independent variables, and the $\beta 1$ value should be significant; in the second step we examine the relationship between independent variables and mediator variable, and the $\beta 2$ value should be significant as well. In the third step we input the independent variables and mediator variable together, treating them as the explaining variables, and then examine their relationship with performance. In the third step, if the coefficient $\beta 3$ between the independent variables and dependent variable is lower than 
$\beta 1$ in the first step, then there exists a mediating effect. And simultaneously if $\beta 3$ is significant, there exists a partial mediating effect. Should $\beta 3$ be non-significant, there exists a complete mediating effect. Table Five shows that H3a is not supported because the coefficient of resource purchase and performance in step $3\left(0.224^{* *}\right)$ is higher than that in step one $\left(0.16^{* *}\right)$. However, H3b is supported, as learning capability has a partial mediating effect between resource attraction and new venture performance. H3c is also supported, as learning capability has a complete mediating effect between resource internal development and new venture performance.

The final results are illustrated in Figure Two.

----------Insert Figure Two here

\section{Discussion, implications, and limitations}

The aim of this study is to explore the relationship between resource acquisition and performance in Chinese new ventures. Specifically, we focus on three means of resource acquisition, and question whether they have the same effect on performance. The second aim of this study is to analyze the mechanisms influencing the relationship between resource acquisition and performance. Therein we introduce learning capability to be an intermediate variable, and examine its mediating role between resource acquisition and new venture performance. Our work is motivated by discontent present in entrepreneurship and strategic management literatures about the poor state of knowledge and understanding we have about the black box of value creation from firm's resource acquisition activities and the performance of firms.

We find that all the three methods of resource acquisition have positive direct effects on 
the new venture performance of Chinese firms. These results are consistent with previous studies focusing on new ventures in Western market economies. Relative to their counterparts in market economies, our study focuses on the transformational mechanism between resource acquisition and new venture performance in transition economies in which information is highly asymmetrical and strategic factor markets are under-developed. Our study contributes to this line of research by empirically demonstrating how learning capability mediates the relationship between various methods of resources acquisition and new venture performance in China's transitional economy. Learning capability does not have a mediating effect between resource purchase and performance, but it does have a mediating effect between resource attraction and performance as well as between resource internal development and performance in new ventures. The three methods of resource acquisition might therefore be thought of as synchronized instead of mutually exclusive in terms of seeking and securing superior new venture performance. Our findings therefore contribute to knowledge on the 'entrepreneurial challenge' of constructing a resource base in the absence of resource strength and the relative contribution of different resource acquisition methods to firm performance as called for by Brush et al. (2001).

It is interesting that learning capability has no mediating effect between resource purchase and performance but has a partial mediating effect between resource attraction and performance, also has a complete mediating effect between resource internal development and performance. Two explanations from a theory perspective exist. First, resources purchased from the market tend to be physical or tangible in nature (such as land or equipments) whereas the know-how needed to unlock competitively sustainable value from 
them requires longer-term learning and experimentation, and the combining of these purchased resources with other forms of (intangible) resources and capabilities. Indeed, the major advantage associated with purchasing resources rests in the firm's ability to secure them at below true cost from the factor market (Barney 1986). Second, it might also be the case that the learning encounters generated by engaging in resource purchasing are simply too transactions based to fuel motivation and change in the process of forming a learning capability. Put simply, the learning encounters and the learning opportunities presented through resource purchasing are too simplistic, imitative through experience and offer modest learning value. Without a sense of value or importance attached to the learning encounter, employees dismiss its relevance to the firm's broader operations, focusing their energies instead on learning from resource attraction, which is built around a complex social process of interaction among the firm's members and external actors (it is worth noting that Kogut and Zander [1992] posited that organizational learning is social in nature and thus requires social interaction to spark a rich process of learning). This social interaction generates near-constant learning opportunities that motivate the formation of a learning capability by modifying organizational conditions that can readily enable the firm to take advantage of these opportunities. A similar principle applies to internal resource development in that the process of experimentation, exploration, bundling, and restructuring that take place during the internal development of new resources and new resource combinations is inherently a social process relying on knowledge transfer and integration, problem-solving, and knowledge creation among individuals. This process also creates the requisite motivation to reshape organizational conditions to favor the growth of a learning capability. Our findings caution 
managers and researchers from assuming that each method of resource acquisition is equally valuable or universally valid in improving learning capability as a pathway to improving performance. These findings therefore contribute new knowledge towards resolving the black box of resource conversion into new venture performance as called for by Sirmon et al. (2007). The RBV principle of resource ownership as the driver of firm performance and competitive advantage is inadequate in the absence of resource strength. When entrepreneurs face a persistent challenge to construct a resource base, sustained improvements in firm performance comes from the entrepreneurs' strategic use of resource acquisition methods and managing proactively their relationship with the learning capability of the firm. Our work offers a framework to explore this black box further.

Helfat and Peteraf (2003, p.997) have argued that "it is difficult to fully explain how firms use resources and capabilities to create a competitive advantage”. From our study findings we can suggest that integrating the RBV with organization learning theory can open useful pathways to explaining the conversion of resources to performance. We do find support for the general principle in the RBV that acquiring greater stocks of resources can increase new venture performance and alleviate the liabilities of newness in that sense, but a better way to more completely understand this conversion process is to appreciate how the firm must develop a learning capability to obtain further performance rewards. While the process of resource acquisition itself unlocks learning opportunities that motivate the formation of a learning capability, it is apparent that the debate can be taken forward by studying more closely the formation of a learning capability through firm-level and individual-level activities. Our contribution is to disentangle the role of resource acquisition 
and its dynamic relationship with learning capability but further contributions might come from unraveling further how this learning capability is generated and organized. Thus, we build on work into the learning advantages of newness believed to exist in new ventures (Autio et al. 2000; Sapienza et al. 2006).

The Chinese origin of the firms in our study might influence the broader applicability of our findings, but, we do believe that the logic of our conceptual framework is not contentious. Indeed, new ventures regardless of their place of origin suffer from liabilities of newness and legitimacy weaknesses that render them vulnerable to their inadequate resource strengths. In the absence of resource strengths, new ventures must construct a resource base. Any entrepreneur will encounter the problems of information asymmetry and pessimism from resource providers - hence the 'entrepreneurial challenge’ referred to by Brush et al. (2001) in their study of resource acquisition by US new ventures. In China, these problems are amplified by the uncertainty surrounding the transitions currently taking place in its institutional environments. Thus, one might expect that the problems caused by information asymmetry and gaps in legitimacy for new ventures are amplified in the Chinese context. Thus, our findings are likely to hold in other contexts that exhibit similar or less fierce levels of institutional uncertainty wherein information asymmetry and gaps in legitimacy will still be valid, but implant less strenuous complications on an entrepreneur's endeavors to build purchase, attract, and develop a resource base.

Implications for Managers and Practitioners. China is experiencing economic transformation such that new ventures face a highly dynamic environment as a consequence of it. Because of this, new ventures need to make efforts to find effective ways to acquire 
resources. Our results show that new ventures can select purchasing resources, attracting resources, and developing resources internally as strategies to improve their performance. But a logical question that emerges is how does resource purchase translate to performance returns given it is not mediated by learning capability, and appears to negatively affect the formation of a learning capability in small new ventures? This might be addressed by evaluating how different resource acquisition strategies coalesce and blend together to create value. Our study has examined the three chief resource acquisition methods as independent but it is possible that they interact with each other to shape unique forms of value.

Further important issues for managers in new ventures do emerge. First, in facing an uncertain environment and lacking relevant information compared with Western firms, Chinese entrepreneurs need to identify the potential value of resources in factor markets, and they should decide whether to buy them and how to buy them, or whether alternative methods should be used-ones that offer better opportunities to simultaneously build the firm's learning capability en route to improving firm performance. Second, in transition economies, a network is one of the most important conditions to new ventures' success. Chinese entrepreneurs should seek to build extensive relationships and attract resources through these relationships. This means carefully managing the emerging social capital (and its guanxi equivalent) between the firm and its (potential) resource partners. Entrepreneurs can make use of reputation, business plans, or facilities to attract resources (Brush et al. 2001) but given our observations regarding learning capability, it seems more apparent that the value is not in presenting legitimacy in this way but building legitimacy for resource access and learning through strengthening social interaction among the firm and its resource providers. Third, it is 
important for new ventures to accumulate resources inside the firm to improve competitive advantage and performance given asymmetric information and the unpredictable environment changes in China. Taking human resource and technology resource as examples, because these are harder to imitate and surface from bundling different resources together into novel combinations, greater amounts of knowledge and skills can accumulate and develop. Because internal resource development sparks such rich learning opportunities, it motivates the firm to change routines and processes to ones more amenable to enabling learning, thereby encouraging the formation of a learning capability to sustain performance. New ventures do not face the constrains of historical knowledge, business models, and standardized procedures in the way that established firms do (Autio et al. 2000; Sapienza et al. 2006) and so the experimentation and exploration that comes with internal resource development presents a unique set of opportunities to increase performance but also shape a strong learning capability that further underpins performance against rivals.

For Chinese new ventures to improve performance through learning capability, they should prefer resource attraction and internal development activities above resource purchase. According to our empirical study results, learning capability has no mediating effect between resource purchase and new venture performance. However, new ventures can select the other two means of resource acquisition to improve performance through improving learning capability. For example, Chinese entrepreneurs can attract human, physical, and financial resources by their knowledge, reputation, and relationships. Resource attraction can promote new ventures' learning capability, particularly intangible resources attraction, such as knowledge and information. Resource internal development can improve new venture 
performance through the firm's internal group learning and making use of resource and capabilities in an accumulation process that forms new resources and capabilities in turn (Sirmon et al. 2007). Resources developed internally are typically much more unique than those purchased from factor markets and are owned by the firm such that rents from these resources are locked into the firm. Resources attracted into the firm while typically reshaped by the new venture through its learning are still in some shape or form external to the firm as well and may be attracted by others' networking activities. In turn, it would appear important that entrepreneurs mix their resource acquisition activities not just to acquire diverse resources but as to spark idiosyncratic learning experiences that fuel a learning capability as a pathway to building improvements in firm performance. We contend that longer-term performance returns lie in the learning capability of the firm and not necessarily in its resource acquisition.

Limitations and Future Research. There are several limitations to this study. First, interaction effects might exist among the three methods of resource acquisition and new ventures performance that we do not account for in this study. Second, we use cross-sectional data to study the relationships among resource acquisition, learning capability, and new venture performance. This prevents us to understand the full range of influencing mechanism between the former and the latter. A longitudinal study would help resolve this. Third, our sample is somewhat constrained and only came from three districts in China. To increase representativeness, future study should enlarge the sample scale from different locations and different industries. Fourth, our findings may be affected by the nature of the operating culture and climate in China and so the results may not generalize to other contexts cleanly. 
Moreover, the criteria defining 'small' and 'new venture' firms in China are quite different compared to EU and US definitions. Thus, further research is needed to assess whether the relationships found in this study might differ in firms located in other continents. Still, there is nothing inherently controversial in what we find and, in theory, Western firms ought to benefit from more amenable institutional environments in which to access resources and establish a learning capability. We would expect our findings to be stronger and not different in such firms. Fifth, we only draw on learning capability as a mediator but our analysis indicates the likelihood that further constructs might moderate the relationships between resource acquisition and new venture performance.

Further avenues for future research emerge from our study. First, the measurement instrument for resource acquisition should be improved. For example, some research exists on resource management processes such as how to structure the firm's resource portfolio, bundle resources into capabilities, and formulate leveraging strategies that exploit the firm's capabilities to create value. Our study focuses on only the former part of resource management. In future, more research is needed to focus on the latter sub-processes if we are to further unravel the black box of value creation for the firm's ownership and acquisition of resources. Second, our study speaks to a broad range of resources in an enterprise. In future, research might benefit from examining differences in resource acquisition and leverage among groups of resources. Empirical research to this end could help shed light on where entrepreneur managers might best focus their attention to internally develop or externally acquire specific types of resources, for example. More work is needed to disentangle relationships among resource acquisition, resource bundling, and resource leveraging when 
accounting for the type of resource sought by a firm. The theoretical model we have presented provides a base for new research on the management of resources in new ventures.

\section{Conclusions}

We demonstrate that resource purchase, attraction, and internal development all offer pathways to improving firm performance through resource acquisition. This supports the RBV principle that the unique stocks of resources a firm is able to acquire and internalize provide idiosyncratic routes to improving firm performance in new ventures. But, we contend that longer-term performance returns lie in the learning capability of the firm and not in its resource acquisition. Our findings in this respect contribute towards resolving the growing dissatisfaction with the RBV: the view that the ownership of resources alone cannot explain sustained improvements in firm performance because the black box of resource conversion remains obscure. Nonetheless, while we take a step towards resolving this problem, many more fruitful avenues for investigation remain and we encourage scholars to develop further efforts in this direction.

\section{References}

Akgün, A.E., H. Keskin, J.C. Byrne, and S. Aren (2007). "Emotional and Learning Capability and Their Impact on Product Innovativeness and Firm Performance," Technovation, 27(9), 501-513.

Alvarez, S., and L. Busenitz (2001). "The Entrepreneurship of Resource Based Theory," Journal of Management, 27, 755-775.

Argote, L., and P. Ingram (2000). "Knowledge Transfer: A Basis for Competitive Advantage in Firms,” Organizational Behavior and Human Decision Processes, 82 (1),150-169.

Argote, L., B. McEvily, and R. Reagans (2003). "Managing Knowledge in Organizations: An Integrative Framework and Review of Emerging Themes,” Management Science, 49(4), 571-582.

Argyris, C., and D.A. Schon (1978). Organizational Learning: A Theory of Action Perspective. Reading, MA: Addison-Wesley. 
Atuahene-Gima, K. (2005). "Resolving the Capability-Rigidity Paradox in New Product Innovation,” Journal of Marketing, 69(4), 61-83.

Audretsch, D.B., and E. Lehmann (2006). "Entrepreneurial Access and Absorption of Knowledge Spillovers: Strategic Board and Managerial Composition for Competitive Advantage,” Journal of Small Business Management, 44(2), 155-166.

Autio, E., H.J. Sapienza, and J.G. Almeida (2000). "Effects of Age at Entry, Knowledge Intensity, and Imitability on International Growth,” Academy of Management Journal, 43, 909-924.

Barney, J. (1986). "Strategic Factor Markets: Expectations, Luck, and Business Strategy,” Management science, 32(10), 1231-1241.

Barney, J. (1991). "Firm Resources and Sustained Competitive Advantage,” Journal of Management, 17(1), 99-120.

Barney, J.B., and A.M. Arikan (2001). "The Resource-Based View: Origins and Implications," In Handbook of Strategic Management, Eds. M. A. Hitt, R. E. Freeman, and J. S. Harrison, Oxford, England: Blackwell Publishers,124- 188.

Baron, R., and D. Kenny (1986). "The Moderator-Mediator Variable Distinction in Social Psychological Research: Conceptual, Strategic, and Statistical Consideration,” Journal of Personality and Social Psychology, 51, 1173-1182.

Biggadike, E.R. (1979). Corporate Diversification: Entry, Strategy and Performance. Boston: Division of Research, Graduate School of Business Administration, Harvard University.

Bollen, K.A. (1989). Structural Equations with Latent Variables. New York: John Wiley and Sons.

Bowman, C., and N. Collier (2006). "A Contingency Approach to Resource-Creation Processes,” International Journal of Management Reviews, 8 (4), 191 - 211.

Brush, C.G., and P. A. Vanderwerf (1992). "A Comparison of Methods and Sources for Obtaining Estimates of New Venture Performance,” Journal of Business Venturing, 7 (2), 157-170.

Brush, C.G., P.G. Greene, M.M. Hart, and H.S. Haller (2001). "From Initial Idea to Unique Advantage: The Entrepreneurial Challenge of Constructing a Resource Base,” Academy of Management Executive, 15(1), 64-78.

Castrogiovanni, G.J. (1991). "Environmental Munificence: A Theoretical Assessment," Academy of Management Review, 16: 542-565.

Chandler, G.N., and S.H. Hanks (1994). "Market Attractiveness, Resource-Based Capabilities, Venture Strategies, and Venture Performance," Journal of Business Venturing, 9(4), 331-349.

Chi, T. (1994). “Trading in Strategic Resources: Necessary Conditions, Transaction Cost Problems, and Choice of Exchange Structure,” Strategic Management Journal, 15(4), 271-290.

Chiva, R., J. Alegre, and R. Lapiedra (2007). "Measuring Organisational Learning Capability among the Workforce,” International Journal of Manpower, 28(3-4), 224-242.

Cohen, W.M., and D.A. Levinthal (1990). "Absorptive Capacity: A New Perspective on Learning and Innovation,” Administrative Science Quarterly, 35, 128-152.

Costa, I., and S.R.R.Queiroz (2002). "Foreign Direct Investment and Technological Capabilities in Brazilian Industry,” Research Policy, 31(8-9), 1431-1443. 
Covin, J.G., and D.P. Slevin (1991). "A Conceptual Model of Entrepreneurship as Firm Behavior,” Entrepreneurship: Theory and Practice, 16(1), 7-24.

Crossan, M., H.W. Lane, and R.E. White (1999). “An Organizational Learning Framework: From Intuition to Institution,” Academy of Management Review, 24(3), 522-537.

Das, T.K., and B.S.Teng (2000). “A Resource-Based Theory of Strategic Alliances,” Journal of Management, 26(1), 31-61.

Denrell, J. (2003). "Vicarious Learning, Undersampling of Failure, and the Myths of Management,” Organization Science, 14 (3), 227-243.

DiBella, A.J., E.C. Nevis, and J.M. Gould (1996). "Understanding Organizational Learning Capability,” Journal of Management Studies, 33(3), 361-379.

Dushnitsky, G. (2010). "Entrepreneurial Optimism in the Market for Technology Inventions," Organization Science, 21(1), 150-167.

Eisenhardt, K.M., and J. Martin (2000), “Dynamic Capabilities: What are They?” Strategic Management Journal, 21, 1105-1121.

Eisenhardt, K.M., and C.B. Schoonhoven (1996). "Resource-Based View of Strategic Alliance Formation: Strategic and Social Effects in Entrepreneurial Firms," Organization Science, 7(2), 136-150.

Fiol, C.M., and M.A. Lyles (1985). “Organizational Learning,” Academy of Management Review, 10(4), 803-813.

Gerwin, D, and H. Kolodny (1992). Management of Advanced Manufacturing Technology: Strategy, Organization, and Innovation. New York: John Wiley and Sons.

Garvin, D.A. (2000). Learning in Action: A Guide to Putting the Learning Organization to Work, Boston: Harvard Business School Press.

Gilbert, B.A., P.P. McDougall, and D.B. Audretsch (2008). "Clusters, knowledge spillovers and new venture performance: An empirical examination,” Journal of Business Venturing, 23(4), 405-422.

Goh, S.C. (1998). "Toward a Learning Organization: the Strategic Building Blocks,” SAM Advanced Management Journal, 62(2), 15-21.

Goh, S., and G. Richards (1997). "Benchmarking the Learning Capacity of Organizations,” European Management Journal, 15(5), 575-583.

Gulati, R., N. Nohria, and A. Zaheer (2000). “Strategic Networks,” Strategic Management Journal, 21, 203-215.

Hall, J., and C.W. Hofer (1993). "Venture Capitalists' Decision Criteria in New Venture Evaluation,” Journal of Business Venturing, 8(1), 25-42.

Hall R.H. (1987). Organizations: Structures, Processes and Outcomes. Englewood Cliffs, NJ: Prentice-Hall.

He, Z.L., and P. K. Wong (2004). "Exploration vs. Exploitation: An Empirical Test of the Ambidexterity Hypothesis,” Organization Science, 15(4), 481-494.

Helfat, C.E., and M.A. Peteraf (2003). “The Dynamic Resource-Based View: Capability Lifecycles,” Strategic Management Journal, 24(10), 997-1010.

Henderson, A. (1999). "Firm Strategy and Age Dependence: A Contingent View of the Liabilities of Newness, Adolescence and Obsolescence”, Administrative Science Quarterly, 44, 281-314.

Hite, J.M., and W.S. Hesterly (2001). “The Evolution of Firm Networks: From Emergence to 
Early Growth of the Firm,” Strategic Management Journal, 22, 275-286.

Hitt, M.A., D. Ahlstrom, M. T. Dacin, E. Levitas, and L. Svobodina (2004). "The Institutional Effects on Strategic Alliance Partner Selection in Transition Economies: China vs. Russia,” Organization Science, 15(2), 173-185.

Hsu, H.Y., and W.C. Fang (2009). "Intellectual Capital and New Product Development Performance: The Mediating Role of Organizational Learning Capability,” Technological Forecasting and Social Change, 76(5), 664-677.

Hughes, M., R.D. Ireland, and R.E. Morgan (2007). "Stimulating Dynamic Value: Social Capital and Business Incubation as a Pathway to Competitive Success," Long Range Planning, 40(2), 154-177.

Hult, G.T.M., and O.C. Ferrell (1997). "Global Organizational Learning Capacity in Purchasing: Construct and Measurement,” Journal of Business Research, 40, 97-111.

Jennings, P., and G. Beaver (1997). "The Performance and Competitive Advantage of Small Firms: A Management Perspective,” International Small Business Journal, 15(2), 63-75.

Jerez-Gómez, P., J. Céspedes-Lorente, and R. Valle-Cabrera (2005). "Organizational Learning Capability: A Proposal of Measurement,” Journal of Business Research, 58(6), 715-725.

Johnson, J.L., and R.S. Sohi (2003). “The Development of Inter-firm Partnering Competence: Platforms for Learning, Learning Activities, and Consequences of Learning," Journal of Business Research, 56(9), 757-766.

Kogut, B., and U. Zander (1992). "Knowledge of the Firm, Combinative Capabilities, and the Replication of Technology,” Organization Science, 3, 383-397.

Lane, P.J., and M. Lubatkin (1998). "Relative Absorptive Capacity and Inter-organizational Learning,” Strategic Management Journal, 19, 461-477.

Lei, D., J.W. Slocum, and R.A. Pitts (1999). "Designing Organizations for Competitive Advantage: The Power of Unlearning and Learning," Organizational Dynamics, 37(3), 24-38.

Lemon, M., and P.S. Sahota (2004). "Organizational Culture as a Knowledge Repository for Increased Innovative Capacity,” Technovation, 24(6), 483-498.

Leonard-Barton D. (1992). "Core Capabilities and Core Rigidities: A Paradox in Managing New Product Development,” Strategic Management Journal, 13, 111-125.

Lounsbury, M., and M.A. Glynn (2001). "Cultural Entrepreneurship: Stories, Legitimacy, and the Acquisition of Resources,” Strategic Management Journal, 22, 545-564.

Lumpkin, G.T., and G.G. Dess (2001). "Linking Two Dimensions of Entrepreneurial Orientation to Firm Performance: The Moderating Role of Environment and Industry Life Cycle,” Journal of Business Venturing, 16(5), 429-451.

Lynn, G.S., and A.E. Akgun (2000). "A New Product Development Learning Model: Antecedents and Consequences of Declarative and Procedural Knowledge," International Journal of Technology, 20 (5-8), 490-510.

Makino, S., and A. Delios (1996). "Local Knowledge Transfer and Performance: Implications for Alliance Formation in Asia,” Journal of International Business Studies, 27(5), 905-927.

March, J.G. (1991). "Exploration and Exploitation in Organizational Learning,” Organization Science, 2(1), 71-97. 
Martens, M.L., J.E. Jennings, and P.D. Jennings (2007). "Do the Stories They Tell Get Them the Money They Need? The Role of Entrepreneurial Narratives in Resource Acquisition," Academy of Management Journal, 50(5), 1107-1132.

Mathews J.A. (2003). "Strategizing by Firms in the Presence of Markets for Resources," Industrial and Corporate Change, 12(6), 1157-1193.

McDougall, P., and R. Robinson, Jr. (1990). "New Venture Strategies: An Empirical Identification of Eight 'Archetypes' of Competitive Strategies for Entry,” Strategic Management Journal, 11, 447-467.

Miller, A., and B. Camp (1985). "Exploring Determinants of Success in Corporate Ventures,” Journal of Business Venturing, 1, 87-105.

Molina-Morales, M.F., and M.T. Martínez-Fernández (2010). "Social Networks: Effects of Social Capital on Firm Innovation,” Journal of Small Business Management, 48(2), 258-279.

Murphy, G.B., J.W Trailer, and R.C. Hill (1996). "Measuring Performance in Entrepreneurship,” Journal of Business Research, 36, 15-23.

Nahapiet, J., and S. Ghoshal (1998). "Social Capital, Intellectual Capital, and the Organizational Advantage,” Academy of Management Review, 23, 242-266.

Nunnally, J.C. (1978). Psychometric Theory. New York: McGraw-Hill.

Pfeffer, J., and G.R. Salancik (1978). The External Control of Organizations: A Resource Dependence Perspective. New York: Harper and Row.

Pirolo, L., and M. Presutti (2010). "The Impact of Social Capital on the Start-ups' Performance Growth,” Journal of Small Business Management, 48(2), 197-227.

Podsakoff, P.M., and D.W. Organ (1986). "Self-reports in Organizational Research: Problems and Prospects,” Journal of Management, 12(4), 531-544.

Pollock, T.G., and V.P. Rindova (2003). "Media Legitimation Effects in the Market for Initial Public Offerings,” Academy of Management Journal, 46(5), 631-642.

Premaratne, S.P. (2001). "Networks, Resources, and Small Business Growth: The Experience in Sri Lanka,” Journal of Small Business Management, 39(4), 363-371.

Romanelli, E. (1987). "New venture strategies in the microcomputer industry," California Management Review, 30, 160-175.

Sapienza, H.J., E. Autio, G. George, and S.A. Zahra (2006). “A Capabilities Perspective on the Effects of Early Internationalization of Firm Survival and Growth,” Academy of Management Review, 31(4), 914-933.

Schroeder, R.G., K.A. Bates, and M.A. Junttila (2002). "A Resource-Based View of Manufacturing Strategy and the Relationship to Manufacturing Performance,” Strategic Management Journal, 23(2), 105-117.

Senge, P.M. (1990). The Fifth Discipline: Art and Practice of the Learning Organization. New York: Doubleday.

Shane, S., and D. Cable (2002). "Network ties, Reputation and the Financing of New Ventures,” Management Science, 48(3), 364-381.

Shane S. (2003). A General Theory of Entrepreneurship: The Individual-Opportunity Nexus. Northampton, MA: Edward Elgar.

Shrivastava, P. (1983). “A Typology of Organizational Learning Systems,” Journal of Management Studies, 20(1), 8-28. 
Sinkula, J.M. (1994). “Market Information Processing and Organizational Learning,” Journal of Marketing, 58(1), 35-45.

Sirmon, D.G., and Hitt, M.A. (2003). "Managing Resources: Linking Unique Resources, Management and Wealth Creation in Family Firms," Entrepreneurship Theory \& Practice, 27(4), 339-358.

Sirmon, D.G., M.A. Hitt, and R.D. Ireland (2007). "Managing Firm Resources in Dynamic Environments to Create Value: Looking Inside the Black Box,” Academy of Management Review, 32 (1), 273-292.

Steier, L., and R. Greenwood (2000). "Entrepreneurship and the Evolution of Angel Financial Networks,” Organization Studies, 21(1), 163-192.

Stinchcombe, A. (1965). "Social Structures and Organizations," in Handbook of Organizations. Eds. J. March, Chicago: Rand McNally, 142-193.

Stuart, T.E., H. Hoang, and R.C. Hybels (1999). "Interorganizational Endorsements and the Performance of Entrepreneurial Ventures," Administrative Science Quarterly, 44(2), 315-349.

Szulanski, G. (1996). "Exploring Internal Stickiness Impediments to the Transfer of Best Practice within the Firm,” Strategic Management Journal, 17, 27-44.

Tsai, W. (2001). "Knowledge Transfer in Intraorganizational Networks: Effects of Network Position and Absorptive Capacity on Business Unit Innovation and Performance," Academy of Management Journal, 44(5), 996-1004.

Uhlenbruck, K., K.E. Meyer, and M.A. Hitt (2003). "Organizational Transformation in Transition Economies: Resource Based and Organizational Learning Perspectives," Journal of Management Studies, 40,257-282.

Ulrich D., M.A. Glinow, and T. Jick (1993). "High-impact Learning: Building and Diffusing Learning Capability,” Organizational Dynamics, 22 (2), 52-66.

Venkatraman, N., and V. Ramanujam (1986). "Measurement of Business Performance in Strategy Research: A Comparison of Approaches," Academy of Management Review, 11(4), 801-814.

Vesper, K. H. (1980). New Venture Strategies. Englewood Cliffs, N.J.: Prentice-Hall.

Wong, S., C. Soh, B, Neo, and G. Goren (1993). "The Role of Information Technology in Singapore's New-Venture Development," Journal of Small Business and Entrepreneurship, 10(3), 101-111.

Zhang, J., P.H., Soh, and P.K. Wong (2010). "Entrepreneurial Resource Acquisition through Indirect Ties: Compensatory Effects of Prior Knowledge,” Journal of Management, 36(2), 511-536.

Zahra, S.A. (1993). "Environment, Corporate Entrepreneurship, and Financial Performance: A Taxonomic Approach,” Journal of Business Venturing, 8(4), 319-340. 